\title{
被験者の自由記述回答に基づく地域景観の選好特性に関する研究 A STUDY ON THE CHARACTERISTICS OF THE PREFERENCE FOR REGIONAL LANDSCAPES BASED ON THE FREE DESCRIPTIVE ANSWER BY SUBJECTS
}

\author{
大石洋之*, 村川三郎**, 西名大作*** \\ Hiroshi OISHI, Saburo MURAKAWA and Daisaku NISHINA
}

\begin{abstract}
The purpose of this study is to clarify the usefulness concerning the survey in free descriptive answer style and the evaluation process to decide whether preferable or not, against the familiar regional landscapes recalled by the subjects. First of all, a questionnaire survey on preferable and dis-preferable landscapes in free descriptive answer style to the students of Hiroshima University as subjects was carried out. As for the analysis method of the answers, they were divided into three components, such as 'main object', 'condition of the object' and 'reason for the decision'.

As a result of the survey, the fact that the subjects recalled not only the specific landscape elements, such as trees and buildings, but also the variety combination of landscape elements and whole image of landscapes was found out. In addition, the process of landscape evaluation was grasped by the fact that the relationships between each 'main object' and 'reason for the decision' have the feature which prompts to decide whether preferable or not. On the other hand, we clarified that 'main object' and 'reason for the decision' have the strong effect for separating the landscapes into two groups. However, 'condition of the object' does not have such effect because it is the supplements for 'main object'.
\end{abstract}

Keywords: regional landscapes, characteristics of preference, recalling,

free descriptive answer style, landscape elements

地域景観，選好特性，想起，自由記述回答，景観構成要素

1. 序

近年の経済や産業活動の進展に伴い、地域の生活環境は刻々と変 化してきている。農村地域を例とするなら、大都市周辺部にみられ る人口の集中によるベッドタウン化など、種々の要因により変容の 著しい状況にある。その結果、伝統的な農村景観のみならず、整備 され都市化した新しい景観など、多様な景観の混在した地域が創り 出されることも多く、地域の個性が失われつつあるといえる。

しかし最近では、全国各都市において、魅力的な景観に対する認 識の高まりから、様々なまちづくり活動や、それぞれの地方自治体 が策定した条例による景観の整備・保全が行われるようになってき ており、美しく快適な都市を創るための地域の特長を活かした整備 の方向性が求められている。さらに、2004 年 6 月にいわゆる「景観 緑三法」が公布され、この景観に関する総合的な法律により、良好 な景観の形成に向けた規制が本格的に始動している。

これまで、地域景観について、実際の都市計画や景観整備への反 映を目的として多様な研究が行われ、数多くの知見が得られている。 筆者らも、河川景観やみどり景観を対象として、被験者の心理的評

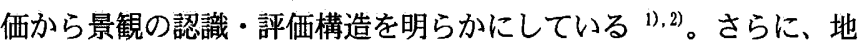
域の景観構成要素を画像処理により合成したスライド映像を用いた
評価実験により、特定の景観構成要素が地域景観の評価に及ぼす影 響についても定量的に把握している ${ }^{3), 4) 。 ~}$

しかしながら、これらの研究では対象となる景観、評価項目のい ずれも研究者が決定しているという制約条件が存在する。このよう な制約から離れ、評価者の多様な視点、自由な考えを抽出すること を意図して、筆者らは、河川景観や住民が撮影した景観について、 自由記述回答の分析を行っている ${ }^{5), 6)}$ 。このうち、前者 ${ }^{5)}$ は予め用 意した河川景観を被験者に呈示したが、後者 ${ }^{6)}$ は撮影者である住民 に自分が撮影した景観に対する自由記述を求めており、評価対象に も制約が課せられていない。

これに類する研究としては、古賀らによるキャプション評価法の

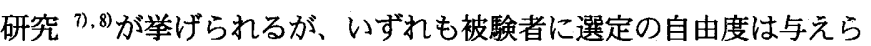
れてはいるものの、評価対象は視認可能な実際の景観である。これ に対して、具体的な景観ではなく、人々の心に残る景観について分 析を試みた研究も存在する。例えば西村ら ${ }^{9}$ は、記憶された風景が 心の中で酲成され心象風景になり、人が風景の価値や意味を理解す る要因になると述べている。同様に、澤田ら ${ }^{10}$ は、強い印象を与え る空間体験が心象風景となり、環境に対する価值基準になるとして いる。したがって、被験者に想起されやすい景観は、被験者の地域
* 広島大学大学院工学研究科 大学院生・修士(工学)

** 広島大学大学院工学研究科 教授. 工博

*** 広島大学大学院工学研究科 助教授・博士 (工学
Graduate Student, Graduate School of Engineering, Hiroshima Univ., M. Eng. Prof., Graduate School of Engineering, Hiroshima Univ., Dr. Eng. Assoc. Prof., Graduate School of Engineering, Hiroshima Univ., Dr. Eng. 
に対する価值観や評価をよ り強く反映したものと考え られ、これらを抽出し検討 することは、地域景観の特 徵を把握するとともに、地 域景観に対する評価構造を 明らかにするうえで重要で あるといえる。

以上のような観点から本 研究は、被験者に好ましい、 または、好ましくない景観 を想起させ、自由記述回答 を求める調査を実施し、そ の回答内容の分析に基づい て、地域で日常的かつ身近 にイメージされる景観につ いて把握する。次いで、景

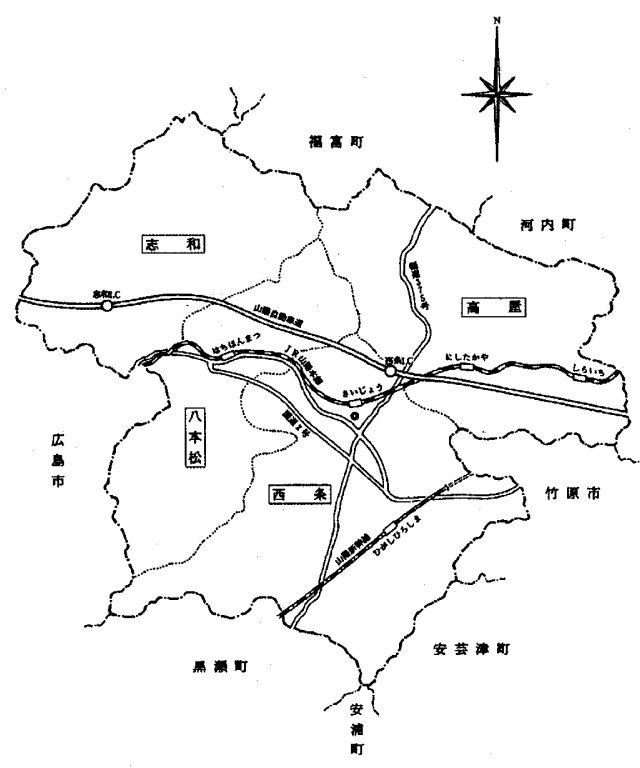

図一1 調查対象地域( …..... 内が東広島市)

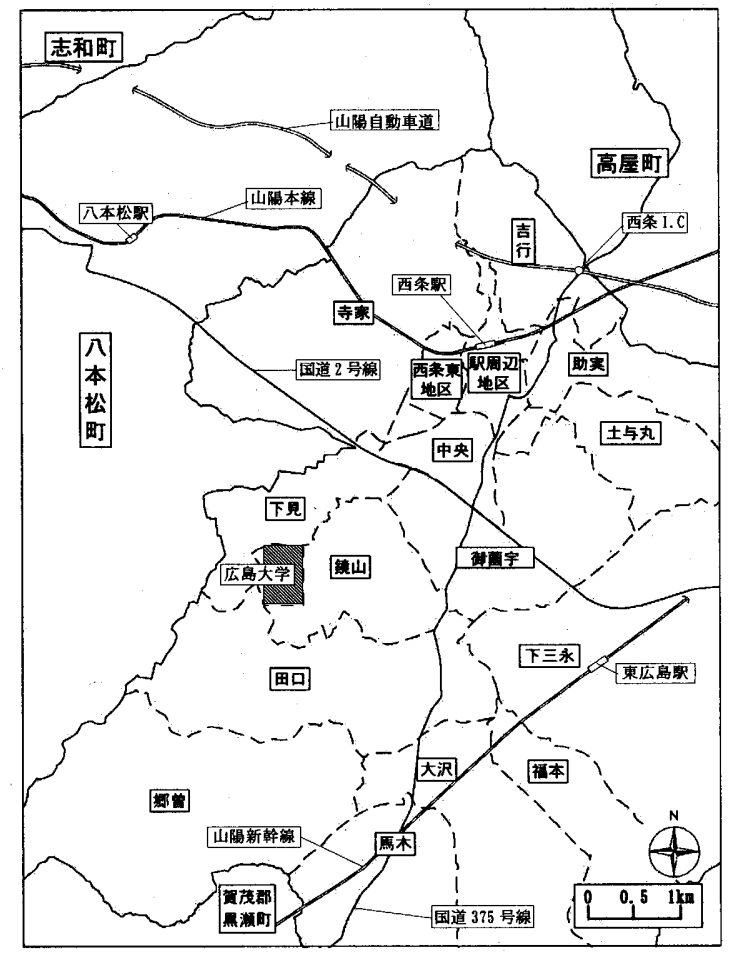

図一2 東広島市西条町の各地域

表一 1 調查実施日および被験者数

\begin{tabular}{c|c|c|c|c||c}
\hline 実施日 & $\begin{array}{c}\text { 1998年 } \\
\text { 7月14日 }\end{array}$ & $\begin{array}{c}\text { 1999年 } \\
\text { 7月19日 }\end{array}$ & $\begin{array}{c}2000 \text { 年 } \\
\text { 7月17日 }\end{array}$ & $\begin{array}{c}2001 \text { 年 } \\
\text { 7月23日 }\end{array}$ & 合計 \\
\hline 被験者数 & 39 & 43 & 42 & 34 & 158 \\
\hline (ᄉ) & & & & & \\
\hline
\end{tabular}

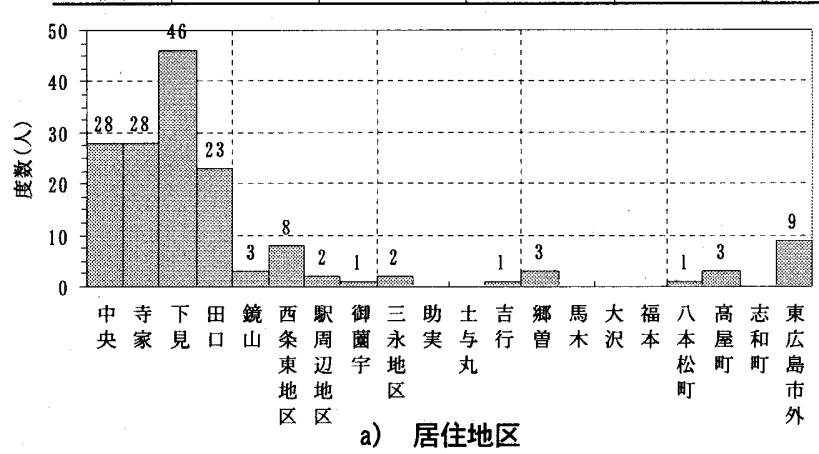

a) 居住地区
回答構成割合

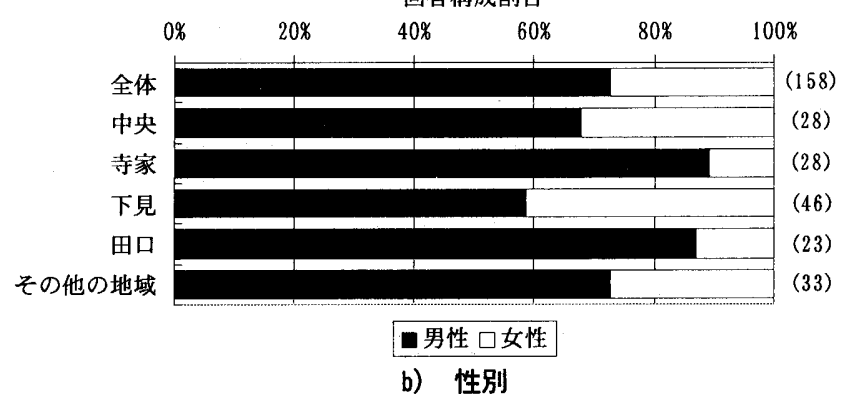

図-3 被験者の属性

東側では田畑や赤瓦屋根の民家による田園風景が広がっている。

\section{2 調查内容・方法}

本調查は、被験者が日常の生活の中で知覚し、イメージとして捉 えている景観の内容、また、共通して好まれる(好まれない)地域の 特徴的な事物、さらには、それらに対する関心や愛着など、人々の 意識を、枠組みを規定せず多様な形で抽出することを意図している。

調查にあたっては、「現在の住居から大学までの通学路の概略を図 示し 注3、そこから見える景観について、好ましい景観と好ましくな 


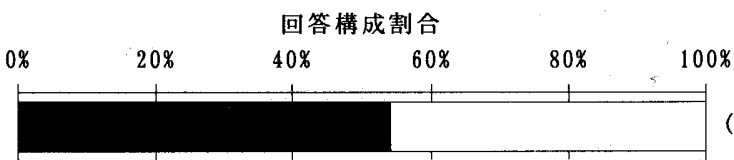

口好ましい景観 口好ましくない景観

図一4 想起詈観の選好の判断による構成割合

い景観を具体的に示し、それを挙げた理由を述べよ。図中に は、その地点から見える方向を矢印で示すこと。」指示し、 被験者に回答を求めた。回答の際は、手元に写真や資料など を置かず、それぞれ影観を想い起こさせることにより自由に 記述させたが、理由や説明の記述量や、好ましい、または好 ましくない景観の指摘数に関しては特に指定せず、B4 サイズ の回答用紙 1 枚程度を目安とさせた。

調査の実施日および被験者数を表一 1 に示す。調查は 1998 〜2001 年にかけて、各年の 7 月下旬に行った、被験者は広島大学に 在籍する学生 (調査時点で 3 回生の工学部建築系の学生) 注4)で、被験 者数は各年 40 人程度であり、分析対象とした被験者数は計 158 人で ある。

\section{3 被験者の属性}

被験者の属性を図ー 3に示す。a) は被験者の居住地区、b) は性別 による回答構成割合である。居住地区については、広島大学に隣接 する「下見」や「田口」、JR 西条駅から「中央」「鏡山」を通り広島 大学へ到る都市計画道路であるブールバールや、「下見」「西条東地 区」を通る下見街道に沿い、通学経路として大学までのアクセスの 容易な「中央」や「寺家」に多く居住している。また、性別では全 体の 7 割が男性であり、学生街として整備の進んでいる「下見」や、 開発により都市的な様相を呈し、比較的新しいアパートやマンショ ンが多く、整備面でも充実している「中央」において、女性の割合 が他の地区に比べ多くなっている。

\section{3． 東広島市域における想起曼覾の指摘位置の分布}

被験者が想起し、回答用紙に記した景観 (以降、想起景観と称す) の地理的な分布傾向を検討する。ここで、想起景観とは、被験者に 記述させた通学路の概略図上における矢印で示された好ましい・好 ましくない景観であり、矢印それぞれの位置をもとに集計している注)。 想起景観の好ましい・好ましくない (以降、選好の判断と称す)別で の回答構成割合を図ー 4 に示す。想起景観の合計数は 464 シーンで あり、被験者 1 人あたり 2.94 シーン想起している。また、好ましい 想起景観と好ましくない想起景観の割合に、それほど大きな偏りは なく、ほぼ同程度想起されている。

想起景観の東広島市域における指摘位置の分布を図ー 5 に示す。 また、市域を構成する各地区別に集計した結果を、居住地域別にみ た被験者数と併せて図ー6に示す。これより、想起景観の分布傾向 についてみるなら、好ましい、好ましくないのいずれの想起景観も ほぼ同様の分布となっていることがわかる。また、通学路上におけ る景観を想起させているため、大学への通学経路である下見街道や ブールバール、「田口」の東西に走る県道下三永一吉川線に沿って指 摘が集中している。なかでも、広島大学と隣接する「下見」の学生 街付近では選好の判断に関わらず、5 以上のシーンが想起されてい る。各地区での集計結果をみるなら、被験者数の最も多い「下見」

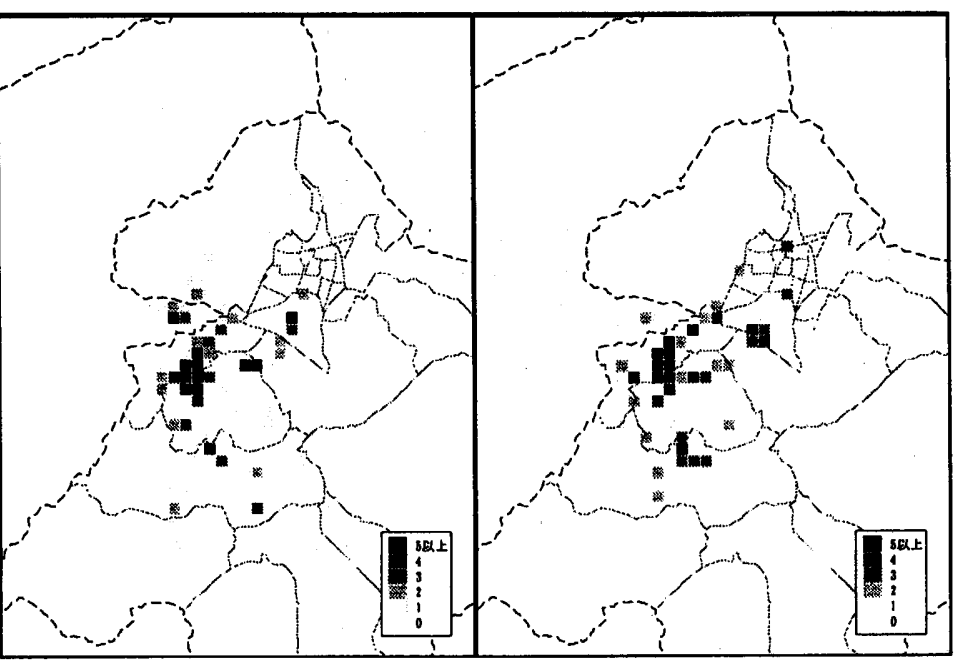

a) 好ましい暴镍

b）好ましくない景钼

図一5＼cjkstart想起量観の指摘位置の分布

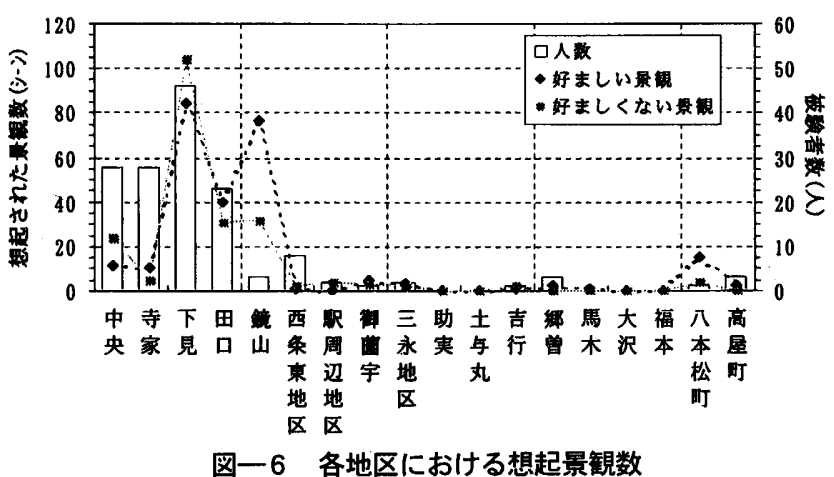

被倹者 $\mathrm{A}$

2 車線の道路と步道との間には並木が植えてあり、緑のトンネルを走って いるようでとても好ましい(a)。また、並木は四季でその表情を変えるので 季節感も感じることができてとても趣がある(b)。

\section{被埃者 B}

横方向に続く R2 バイパスが自然的な空間を切断してしまっていて、せっか くの景観を台無しにしている(c)。

a） 2 車線の道路と歩道との間には 並条 が植えてあり、

$$
\begin{aligned}
& \Longrightarrow \text { 『主な対象』 } \\
& \text { 緑のトンネルを走っているようで好ましい。 } \\
& \text { ら『判断につながる理由』 }
\end{aligned}
$$

b) 並木 は四季でその表情を変えるので、

$\longrightarrow$ 『主な対象』

$$
\begin{aligned}
& \text { 季節感も感じることができて とても趣がある，）好ましい } \\
& \Longrightarrow \text { 対象の状態』 }
\end{aligned}
$$

c）横方向に続く R2 バイパス が自然的な 空間を切断してしまっていて、

$$
\Longrightarrow \text { 主な対象』 } \Rightarrow \text { 対象の状態』 }
$$$$
\text { せっかくの景観を台無しにしている。 } \Rightarrow \text { 恏ましくない }
$$
$\longleftrightarrow$ ら判断につながる理由』

図一7 自由記述回答の分析方法

で想起景観数が多くなっている。これには、「寺家」や「西条東地区」 の被験者が通学時に通過することも多少影響している。また、ブー ルバール沿いの「鏡山」において、多くの景観が想起されている。 
選好の判断別でみるなら、自然的空間が広がり、かつ公園的に整備 されている「鏡山」についてのみ、好ましい景観が好ましくない景 観に比べてかなり多く想起されている。さらに、田園風景の広がっ ている「寺家」や「八本松町」においても、同様の傾向がみられる。
自由記述回答をする際に、多くの人が共通してイメージし、記述しや すい構成要素になるものと考えることができる。

\section{3 『対象の状態』と『判断につながる理由』の分類・集計}

『対象の状態』『判断につながる理由』として抽出された語句に対

\section{4. 自由記述形式による回答内容の分析}

\section{1 分析手順}

被験者による自由記述形式の回答文を整理するにあたり、は じめに回答文の中から、分析対象とする文章の抽出を行った。 被験者によって記述された文章の例と、分析手順を図ー 7 に示 す。被験者Aにみられるように、同一の想起される景観におい て、理由の異なる複数の文章がある場合は、それら全てを区別 して抽出し分析対象とする。このようにして得られた記述文は 合計 643 個であり、被験者 1 人あたりの平均記述数は 4.2 個、 想起景観 1 シーンあたり 1.4 個であった。

続いて、既報 ${ }^{6)}$ の方法に倣い、抽出された各文章を分解・整 理した。文(a)のような場合は、景観構成要素など文章の主部 を示す『主な対象』と、好ましい・好ましくないという評価に 直接的につながる述部である『判断につながる理由』の 2 成分 に分解し、文(b)や文(c)のように、『判断につながる理由』の 前に『主な対象』の特性が補足的に記述されている場合は『対 象の状態』として、3 成分に分解する注 6,7 。各記述文の分解を 行った結果、2 成分に分解されるものは全体の約 7 割であり、 3 成分に分解されるものは約 3 割であった。

既報 ${ }^{6)}$ の結果と比べて、3 成分のうち『対象の状態』を含 む文章数の割合は多くなっており、想起景観の具体的な内容 を指し示すため、自由記述回答に際して、より『主な対象』 を説明する必要性が生じているものと考えられる。

\section{2 『主な対象』の分類・集計}

『主な対象』の集計にあたり、簡単な表記の統一を行うこ とで、まず 122 種類の語句に整理された。そこで、この 122 種類の語句について、その内容によって分類を行う。『主な対 象』の分類と各分類における集計結果を表一 2 に示す。複数 の対象物によって構成される景色や空間が対象となっている 場合は、景観全体として分類し、特定の対象が指摘されてい る場合は、これをさらに 12 種類に分類した。

各分類における指摘数の合計をみると、景観全体や「緑(単 体)」「緑(総体)」「建物」「道路」に対する指摘が多い。選好 の判断別にみるなら、好ましい想起景観については、景観全 体や「緑(単体)」「緑(総体)」「道路」に対する指摘が多いの に対して、好ましくない想起景観の場合は、「建物」や「建造 物」「設置物」「可動物」が多く、「水圏」や「地表面」に対す る指摘もみられる。また、好ましい景観では、緑や「道路」 といった対象が集中的に指搪されるのに対して、好ましくな い景観では様々な対象が指摘される傾向にある。

この結果は、既報 ${ }^{6)}$ と比べ、多少分類に違いはあるが、ほぼ

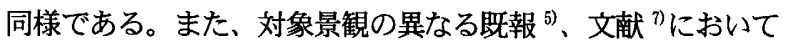
も、「緑」や「建物」「道路」が特徵的に指摘されていることか ら、これらの構成要素は視覚的な捉え易さがあり、印象の残る 対象として強く記憶される可能性が示唆される。したがって、

\section{表-2 『主な対象』の分類と指摘数}

\begin{tabular}{|c|c|c|c|c|c|}
\hline & 略号 & & & 悪 & 合許 \\
\hline $\begin{array}{l}\text { 景観 } \\
\text { 全体 }\end{array}$ & A) 景筧 & 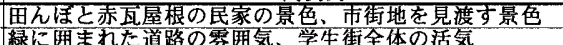 & 132 & 55 & 187 \\
\hline & 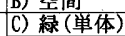 & 木夕夕並木・芝生・草・花・植光込み & 45 & & \\
\hline & D) 緑(総体) & 䜌・田んほ・山・森・林・鼻然・植物 & 50 & 9 & 0 \\
\hline & \begin{tabular}{|l} 
E) 建物 \\
F) 建造物
\end{tabular} & 建物・アパート・酒葴・赤瓦屋根の民家・工場・店舗 & 15 & $\frac{45}{16}$ & 60 \\
\hline & G) 水圈 & 池・池とそのまわり・川゙・川とそのまわり・办面 & 6 & 20 & 26 \\
\hline 持定の & H) 広場 & 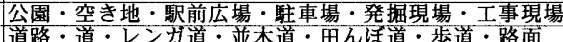 & $\frac{8}{65}$ & 7 & 15 \\
\hline & 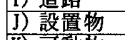 & 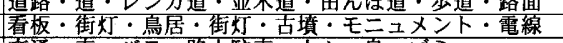 & $\frac{18}{18}$ & & $\frac{105}{49}$ \\
\hline & K) 可動物 & 交通・車・バス・路上駐車・イ々・鳥・コミ & 7 & 30 & 37 \\
\hline & L) 地表面 & 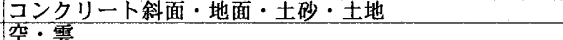 & \begin{tabular}{|ccc}
- \\
2
\end{tabular} & 10 & $-\frac{10}{2}$ \\
\hline & N) その他 & 栥㵊れ日・日陰・色彩 & 14 & 4 & $\frac{L}{18}$ \\
\hline & & 笪据 & 363 & 280 & 643 \\
\hline
\end{tabular}

表ー3 『対象の状態』『判断につながる理由』の分類と指摘数

\begin{tabular}{|c|c|c|c|c|c|c|c|}
\hline \multicolumn{2}{|c|}{ 略号 } & 代表例 & \multicolumn{2}{|c|}{$\begin{array}{ll}\text { 状熊 } \\
\end{array}$} & & if \\
\hline a) 存在 & 1. 存在 & ある・存在しているーな & $\frac{x}{9}$ & 5 & 21 & $\frac{5}{19}$ & 54 \\
\hline b) 多少 & 2. 多少 & 多少 豊か・たくさんあるー少ない & & 18 & 12 & & 54 \\
\hline c) 程度 & & 広狭 広い・広がっているー狭い， & 18 & $\frac{12}{-}$ & 7 & $\frac{4}{-}$ & -41 \\
\hline & & 嵩低 暠い一低い & 2 & 5 & - & - & 7 \\
\hline & & 睘近 彞接している & & 2 & - & $=$ & 2 \\
\hline & & 真つ直ぐー湾曲している & - & 1 & - & - & 1 \\
\hline & & 連続している・続んでいる & 6 & 5 & & 1 & $\frac{1}{11}$ \\
\hline & 4. 明暗 & $\begin{array}{lll} & \\
\text { 明るい一暗い }\end{array}$ & 4 & - & 2 & 6 & $\frac{11}{12}$ \\
\hline d）調和 & 5. 調和 & 調和している一調和していない & 2 & - & 19 & & 48 \\
\hline & & 釟合 n゚ランがとれているーバラスがとれていない & 4 & - & 2 & 6 & 12 \\
\hline & 6. 統- & 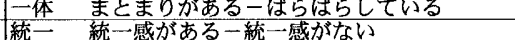 & $\frac{1}{2}$ & $\frac{1}{1}$ & $\frac{1}{4}$ & & $\frac{3}{16}$ \\
\hline & & 夌化 景観に変化がある & $\frac{2}{1}$ & 1 & 1 & 3 & $\frac{10}{6}$ \\
\hline & 7. 整然 & 整然としているー雑然としている & 2 & 5 & 5 & 10 & 22 \\
\hline & & 堂集しているーまばらにある & 1 & & -5 & 3 & 4 \\
\hline & 8. 特徵 & 特徵があるーない & - & - & - & 1 & 1 \\
\hline & 阻害 & 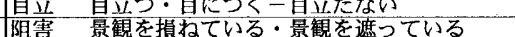 & $=$ & $z$ & 1 & $\frac{3}{21}$ & $\frac{4}{21}$ \\
\hline e) 見元方 & 10. 美酸 & きれい・美しいー污い・美しくな & - & 1 & 57 & & 83 \\
\hline & 11. 鬽力 & 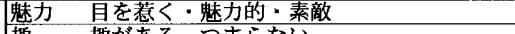 & - & - & 2 & 10 & $\frac{12}{5}$ \\
\hline & & 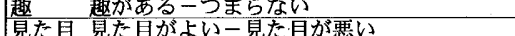 & - & - & $\frac{5}{5}$ & $\overline{-}$ & $\frac{5}{16}$ \\
\hline & 12. 色彩 & 色相 カラフル・色華やか & - & - & 2 & & 2 \\
\hline & & 彩度 急鮮やかー色あせている & 1 & 1 & - & 1 & 3 \\
\hline & & 色のコントラストがある・色合がよい & & & & & -3 \\
\hline 情緒 & 13. 蕜珓 & 眺望＼cjkstart見渡すことができる・見通しがよ & 3 & 2 & 13 & $-\frac{5}{2}$ & $\frac{23}{2}$ \\
\hline & & 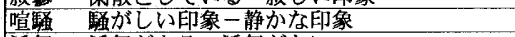 & - & - & $=$ & 2 & $\frac{2}{2}$ \\
\hline & & 活気があるー活気がない & - & - & 4 & 1 & 5 \\
\hline & & 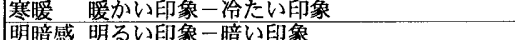 & 1 & $=$ & 1 & 2 & $\frac{4}{3}$ \\
\hline & 15. 圧通 & 厓迫 压迫感があるー開放感がある & 1 & - & 6 & $\frac{1}{16}$ & 23 \\
\hline & & 軽重＼cjkstart軽快ではない・重たり印象 & - & - & & & \\
\hline & & 広狭感 㕕がり感がある-狭苦しい印象 & - & -1 & - & 2 & 5 \\
\hline & 16. 奥行感 & 奥行感 奥行き感がある & - & - & 1 & & \\
\hline & 17. 季節 & 季節 季節感がある・四季の変化がある & 10 & - & 19 & 1 & 30 \\
\hline 药 & 18. 安心 & 心が安らぐ・心地よい & - & - & 12 & & $\frac{12}{10}$ \\
\hline & & 心が和さ・心が㩄される & $=$ & & 10 & & 10 \\
\hline & 19. 長閑 & 長閑・のんびりしている & 1 & - & 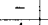 & & 1 \\
\hline & & ゆとりがある・ゆったりとしている & 2 & & 4 & & 6 \\
\hline & 20. 落着 & 心が落ち着 & - & - & 18 & & 18 \\
\hline & 21. 快適 & 快適一不快 & - & - & 3 & 6 & 9 \\
\hline & & 清々しい・爽 & 1 & - & 166 & 1 & 17 \\
\hline & & 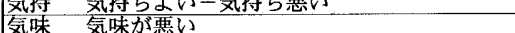 & $\frac{1}{-}$ & - & $\frac{24}{-}$ & $\frac{2}{2}$ & $\frac{21}{2}$ \\
\hline & 22. 気分 & 持ちになる・新鮮な気分に & - & - & 4 & & 4 \\
\hline & & & - & - & 4 & - & 4 \\
\hline h) 自己の & 23. 搘好 & 好きー嫌い & - & - & 7. & 1 & 8 \\
\hline & 24. 印象 & 印象的／印象がよい一悪い & - & - & 3 & 1 & $\frac{4}{7}$ \\
\hline & & 繁囲気がよい一悪い & & & 4 & & \\
\hline & 25. 親近 & 双持てる・親水性が低い & - & - & $\frac{7}{3}$ & 3 & $\frac{10}{3}$ \\
\hline i) 文化. & 26. 地域 & 西条らしい・地域性を感じる & - & - & 4 & 1 & 5 \\
\hline & & 異国 巽国感がある & $\underline{-}$ & - & 1 & - & 1 \\
\hline & 27. 伝統 & 伝統的 & - & - & - & - & {$[-$} \\
\hline & & & & & 2 & - & 3 \\
\hline & & 時代を感じ & 1 & 3 & & 1 & \\
\hline & 28. 自然 & 人工的 & - & -1 & 12 & 2 & 14 \\
\hline & & & 2 & & 3 & & 6 \\
\hline & 29. 整備 & 整備 & 14 & 6 & 16 & 14 & 50 \\
\hline & & とる・取り残 & & & - & 3 & 3 \\
\hline & 30. 利用 & 用しているーしていない & - & $\omega_{-1}$ & 4 & 1 & 5 \\
\hline k) ₹の他 & 危隐 & 案全－危俛鍺びている・生り茂っている & $\frac{-}{4}$ & 11 & $\frac{y}{-}$ & $\frac{21}{12}$ & 27 \\
\hline & 33. 比㖨 & 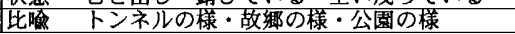 & - & 2 & T & & 4 \\
\hline & & 指摘数合計 & $\overline{110}$ & & & & $\overline{835}$ \\
\hline
\end{tabular}




\section{表-4『主な対象』と『対象の状態』の関連}

\section{a）好ましい景観}

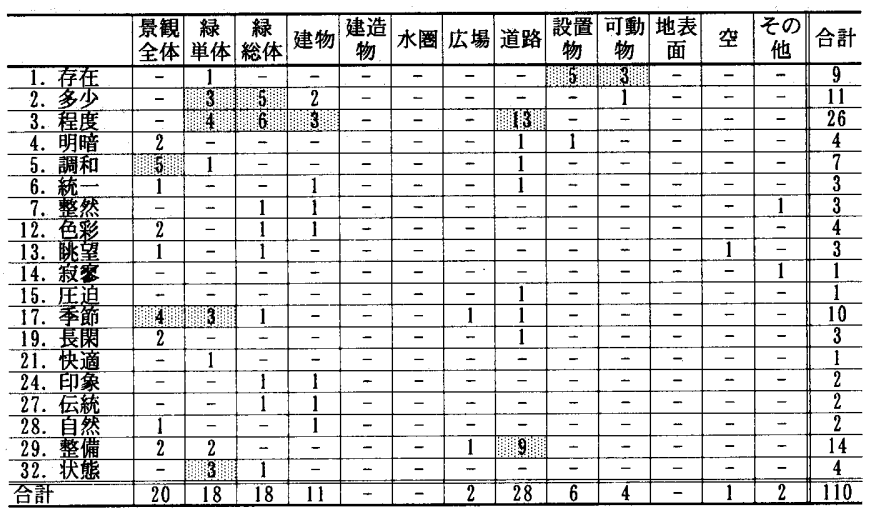

b）好ましくない景観

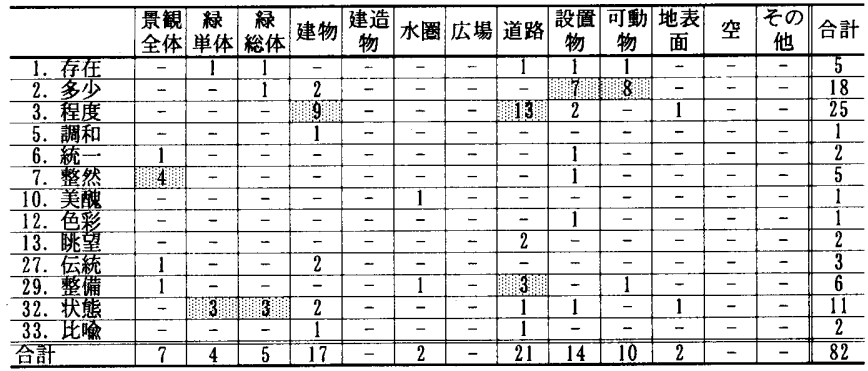

注）網脚讨部分は指摘数が 3 個以上のものを示す

し、『主な対象』と同様に簡単な表記の統一を行った結果、これらを 表す語句は計 186 種類に整理された。

『対象の状態』判断につながる理由』の分類と集計を表ー $3 に$ に示 す。はじめに、表記の統一によって得られた全ての表現を意味内容 によって分類し、既報 5),6)に做い決定した同表に示す 33 分類を分析 に供する。なお、その際「明るい一暗い」など意味内容が対になるも のは同一分類とした。

『対象の状態』についてみると、「存在」や「多少」「程度」「整備」 などに対する指摘が多くなっている。これらはキャプション評洒法” における『特街』と対応した項目であり、『対象の状熊』は『主な対 象』の特徵を現しやすいことがわかる。

一方で、『判断につながる理由』の場合は、「存在」や「調和」「美 醜」「快適」「整備」などが多く指摘されている。「存在」「整備」と いった項目においては『対象の状態』判断につながる理由』の両方 で指摘されているのに対して、「美醜」に代表される見え方に関する 項目や、「快適」などの被験者自身が受ける心理的な作用に関する項 目は、『判断につながる理由』で多く指摘され、『対象の状態』では ほとんど指摘されていないことがわかる。これは、「美醜」と指摘さ れる視覚的な良悪や、心理的な「快適」感が選好の判断を促しやす いと捉えることができる。

また、『主な対象』同様に、指摘される『判断につながる理由』の 項目について、既報 5),6)の結果と比較すると、「調和」や「美醜」な ぞの視覚的な項目への指摘が多いことや、次いで心理的な項目が指 摘されていることなど、類似した傾向がある。しかしながら、文献 7)では、『印象』において視党的な項目よりも、心理的な側面である 「雾囲気」「感情」の項目が多く指摘されている。これは、『印象』 について記述するという教示の存在によって、心理的な印象を指摘

\section{表-5『『主な対象』と『判断につながる理由』の関連}

a) 好ましい景観

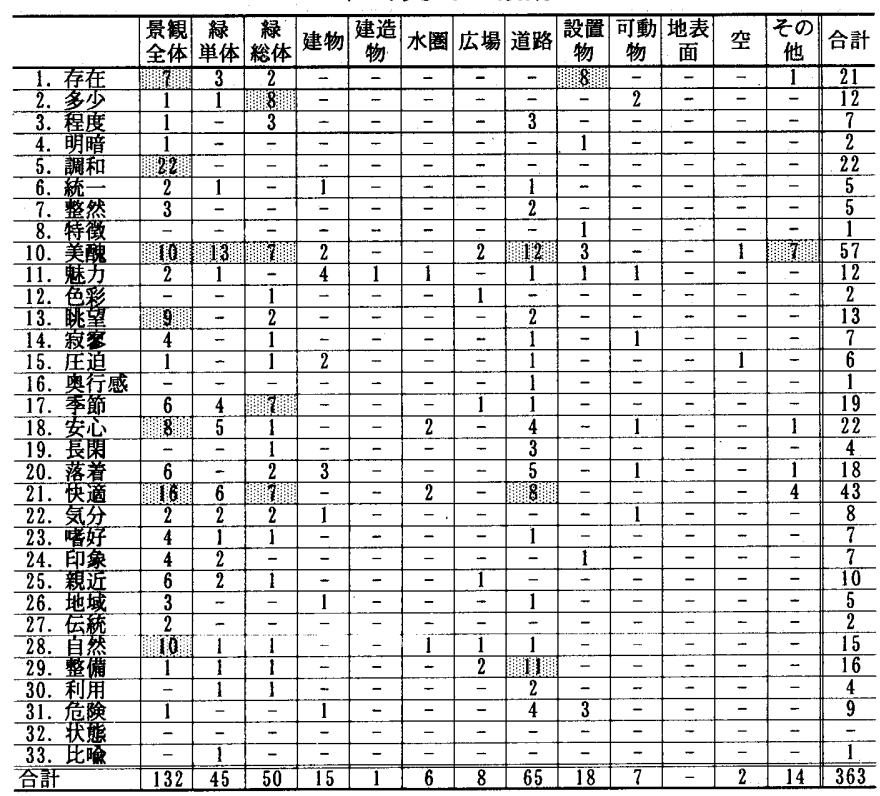

b）好ましくない景観

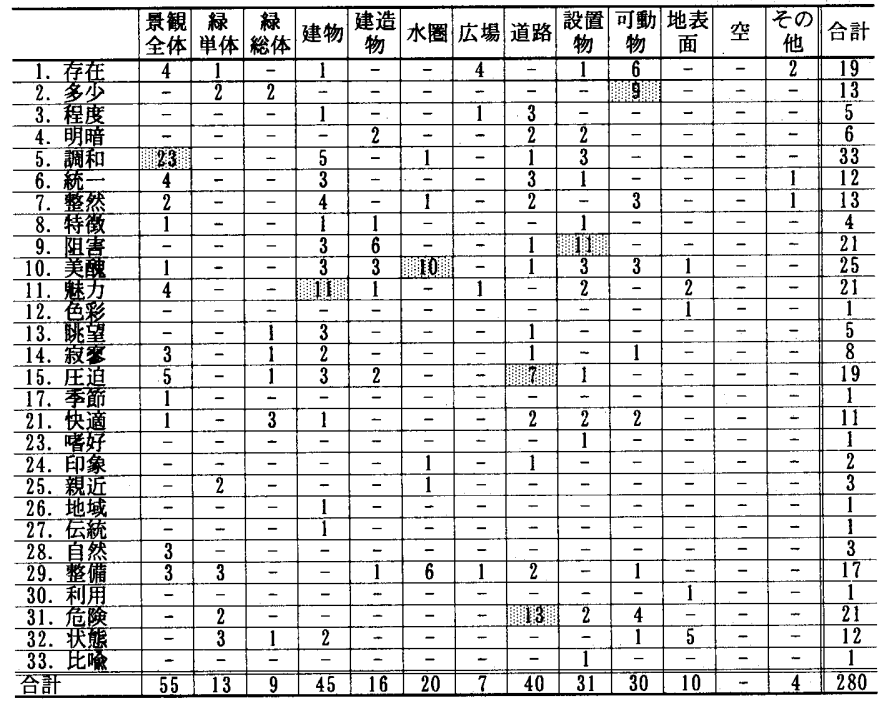

注）網掛け部分は指摘数が 7 值以上のものを示す

しやすい傾向があるのではないかと考えられる。

\section{4 『主な対象』と『対象の状態』『判断につながる理由』の関連}

『主な対象』と『対象の状態』のクロス集計結果を表一 4 に示す。 好ましい景観についてみるなら、「緑(単体)」や「緑(総体)」では、 いずれも「多少」や「程度」などが指摘されており、好ましい景観を 想起する場合には、緑の多さやその広がりといった状態に注目してい ると考えることができる。また、道路については、「程度」や「整備」 に対する指摘が多いことから、広さや整備状況などが注目されている ことがわかる。「設置物」では「存在」についての指摘がみられ、そ の回答の多くが街灯の存在を指摘している。好ましくない景観をみる なら、「道路」においては、好ましい景観と同様に「程度」に対する 指摘が多く、「整備」についても指摘がみられる。また、「設置物」と 「可動物」ではいずれも「多少」において多く指摘されている。

表ー 5 に『主な対象』と『判断につながる理由』のクロス集計結 
果を示す。好ましい景観では、景観全体が対象となっている場合、 「調和」「快適」「美醜」「自然」などが多く指摘されていることから、 全体の調和性や見た目の美しさ、また快適感などを理由として、好 ましい判断が下されていると考えることができる。また、緑(単体)」 「緑(総体)」では、「美醜」「快適」に対する指摘がみられることか ら、緑に対する美しさや快適感による影響の大きいことがわかる。 「道路」については、「美醜」「整備」「快適」が多く指摘されている が、この分類には並木道やレンガ舗装道なども含まれているため、 これらを好ましい景観として想起しているものと推測される。

好ましくない景観についてみるなら、景観全体が対象となってい る場合は、「調和」に指摘が集中している。これより、景観全体が好 ましくないと想起される場合は、その空間を構成している複数の要 素の調和性によって判断されていることがわかる。「建物」について は、「魅力」に対する指摘が多いことから、見た目の平凡さが判断の 理由になっているといえる。

また、看板や電柱などを含む「設置物」については、「阻害」が多 く指摘されている。これを「設置物」の『対象の状態』と関連させ て考察するならば、「設置物」の「多少」すなわち、看板や電柱の 多さが、景観に対する「阻害」要因となって、好ましくないと判断 されるプロセスを考えることができる。

上述の評価・判断のプロセスについて、被験者の記述数による『主 な対象』と『対象の状態』、判断につながる理由』の関係を図 -8 に示す。ここでは、好ましい想起景観において『主な対象』が「景 観全体」の場合と、好ましくない想起景観において『主な対象』が 「建物」の場合を例とした。これより、3 成分の関連により、選好 の判断を行う一連の評価のプロセスが検討できる。なお、以降の文 中の表記として、『対象の状態』の分類は[]で、『判断につながる理 由』の分類は「」で示す。

好ましい場合の景観全体では、[調和] [季節]をはじめ、[明暗] [色 彩] [長閑]といった項目に指摘があり、そこから「美醜」「親近」、あ るいは「快適」といった心理的作用の項目に集中して結びつく傾向 にある。すなわち、景観全体の分類では様々な構成要素の組合せが 考えられ、状態として捉えるときはそれら構成要素の調和やその空 間の持つ季節感などに着目していることが窺え、好ましさへの判断 は、最終的にはその状態から感じる景観全体の美しさや、快適感と いったものが影響していると考えることができる。

一方、好ましくない場合の建物では、[程度]に指摘が集中してい る。すなわち、建物の高さや近さなど、「眺望」に示す見通しの悪さ や、圧迫感を与えるという建てられ方に着目し、好ましくないと評 価される傾向のあることがわかる。

このように、『主な対象』の各分類に対して、それぞれの『対象の 状態』『判断につながる理由』における評価のプロセスが確認でき、 選好の判断に対して『対象の状態』より『判断につながる理由』が 上位項目という階層性を考えるなら、評価グリッド法 ${ }^{12}$ のような景 観選好における評価構造を現していると考えられる。したがって、 自由記述回答から抽出した、多様な項目を有する 3 成分を検討する ことで、景観の選好特性を把握することの可能性が示唆される。

\section{5. 想起景観に対する選好の判断と分類内容の関連}

前章において、想起景観に対する自由記述回答の内容を分析し、

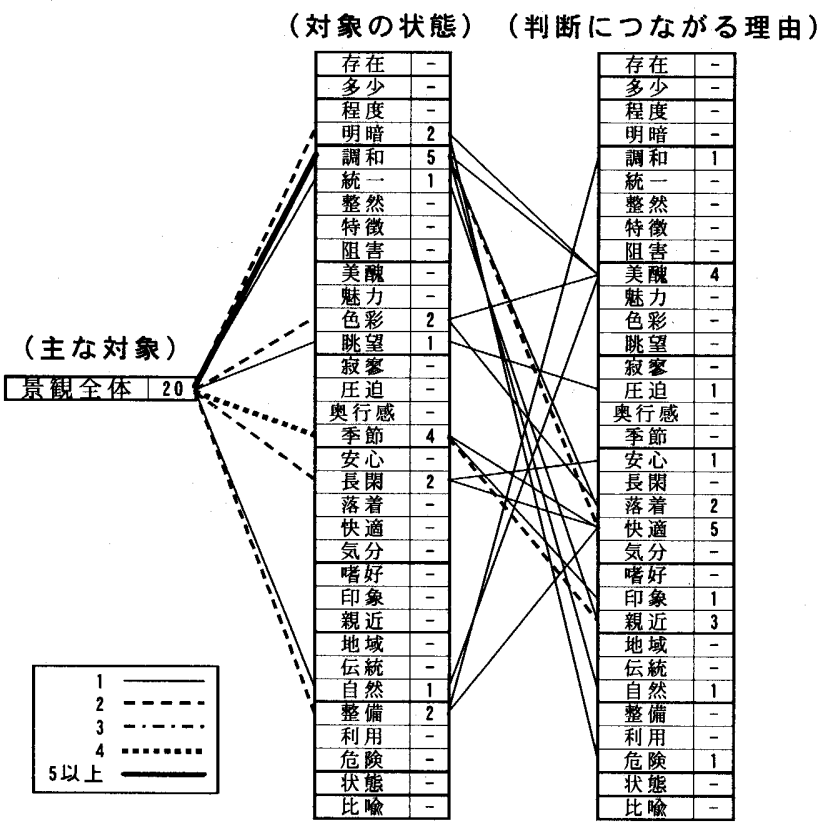

a）景観全体(好ましい景観)

（対象の状態）（判断につながる理由）

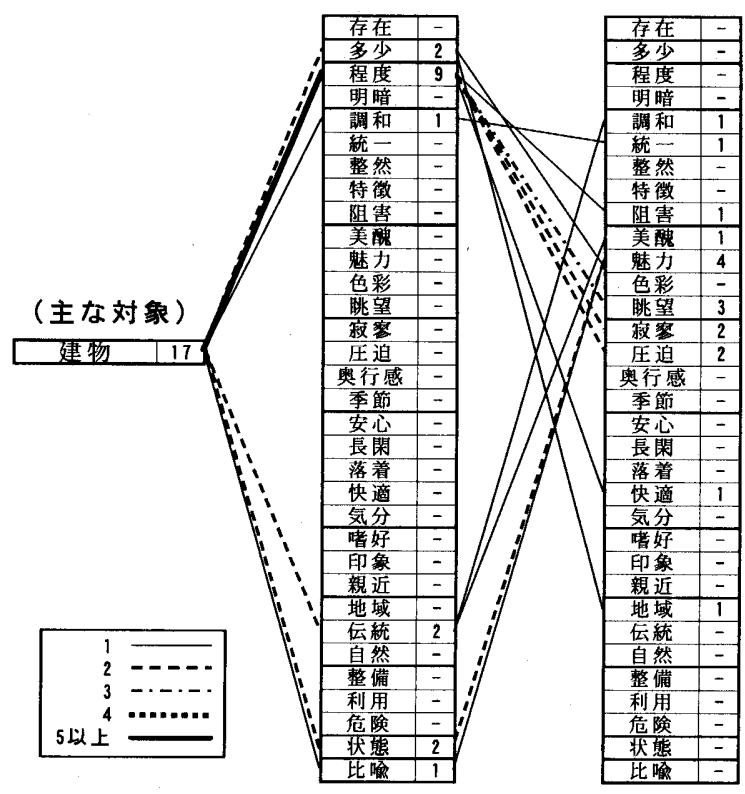

b）建物（好ましくない景観）

\section{図一8３成分による評価・判断のプロセス}

景観を選好する際に、『主な対象』の違いにより、それぞれ選好の判 断に至る特徵的な評価プロセスを示した。

そこで、本章では、分類 3 成分のそれぞれが、選好の判断に及ぼ す影響の程度について検討を行う。『主な対象』『対象の状態』判断 につながる理由』、想起景観の場所を説明変数とし、好ましい・好ま しくないという選好の判断を外的基準とする数量化理論第 II 類によ る分析を行った。結果を表一 6 に示す。相関比は 0.431 となり、あ る程度の判別力は得られている。

これより、選好の判断に対する影響について、偏相関係数の值か ら検討するなら、『主な対象』『判断につながる理由』とも比較的高 い寄与がみられ、想起されている対象とその理由によって、好まし い、または好ましくない景観を判別することができる。また、カテ 
ゴリースコアを選好への影響とみるなら、『判断につながる理由』の 「調和」と「心理的作用」の項目において值が高く、景観を選好す る際にこれらの要因が影響を及ぼしていることがわかる。すなわち、 被験者が選択した『主な対象』については、これらの印象で捉えら れた場合に選好の判断が促されやすいと考えられる。

『対象の状態』については、他の 2 分類に比べると偏相関係数は 低い值を示す。『対象の状態』が『主な対象』の内容を補足するとい う特徴を有する分類であることから、選好の判断に対する奇与が他 の 2 分類に比べて低いものと解釈することができる。したがって、 ここでも選好の判断に対して、『対象の状態』より『判断につながる 理由』が上位項目になっていることがわかる。

\section{6. 結語}

本研究では、都市化による環境の変容の著しい東広島市を対象と して、自由記述回答の分析に基づいて、地域で日常的かつ身近に想 起される景観の内容を把握するとともに、好ましい・好ましくない という選好の判断に至る評価のプロセスを明らかにするため、種々 の検討を行った。得られた知見を以下に示す。

1）自由記述回答の分析方法として、『主な対象』『対象の状態』 『判断につながる理由』という記述文を構成する 3 成分に分解 する手法を用いた。その結果、緑や建物などの特定の構成要素 に着目した景観だけではなく、様々な構成要素の組合せや全体 的なイメージによる景観が多く想起されていることを明らかに し、東広岛市域の多様な景観を反映して、様々な捉え方がされ ていることを示した。また、『判断につながる理由』から、対象 の調和や、美醜といった視覚的な影響、および、対象から被験 者自身が受ける心理的な影響、対象自体が醸し出す雾囲気など が理由となり、選好の判断がなされていることを示した。

2）『主な対象』は、それぞれについて選好の判断を促しやすい 『対象の状態』、判断につながる理由』の特徴がある。例えば、 設置物の[多少]が景観に対する「阻害」であると捉えられるこ とで好ましくないと判断されるといった、『主な対象』から選 好の判断に至る評価プロセスが示唆された。

3）これより、分類 3 成分のつながりを図を用い、評価プロセス の表現とすることで、分類 3 成分によって明確な評価のプロセ スが確認でき、景観を選好する際の特徴を把握することが可能 となることを明らかにした。

4）選好の判断に対して、『主な対象』『対象の状態』『判断につ ながる理由』の 3 成分による影響が確認され、なかでも、『主 な対象』と『判断につながる理由』の 2 成分によって選好の判 断への影響が強いことを明らかにした。また、『対象の状態』 が『主な対象』の状態を補足するという特徵を持つことから、 選好の判断に対する影響が低いことを示した。

以上で得られた知見は、多様な景観の内容を捉え、心理的な評価 プロセスを示していることから、東広島市という地域の景観特性を 明らかにしたものといえる。また、本研究で採用した調查方法にお いては、景観の想起と自由記述回答という 2 点によって、被験者の 自由な発想に基づく評価・回答が得られたと考えられることから、 地域景観評価を検討するうえで、方法論的にも有用性を示すことが

\section{表一 6 選子の判断と分類 3 成分の関連}

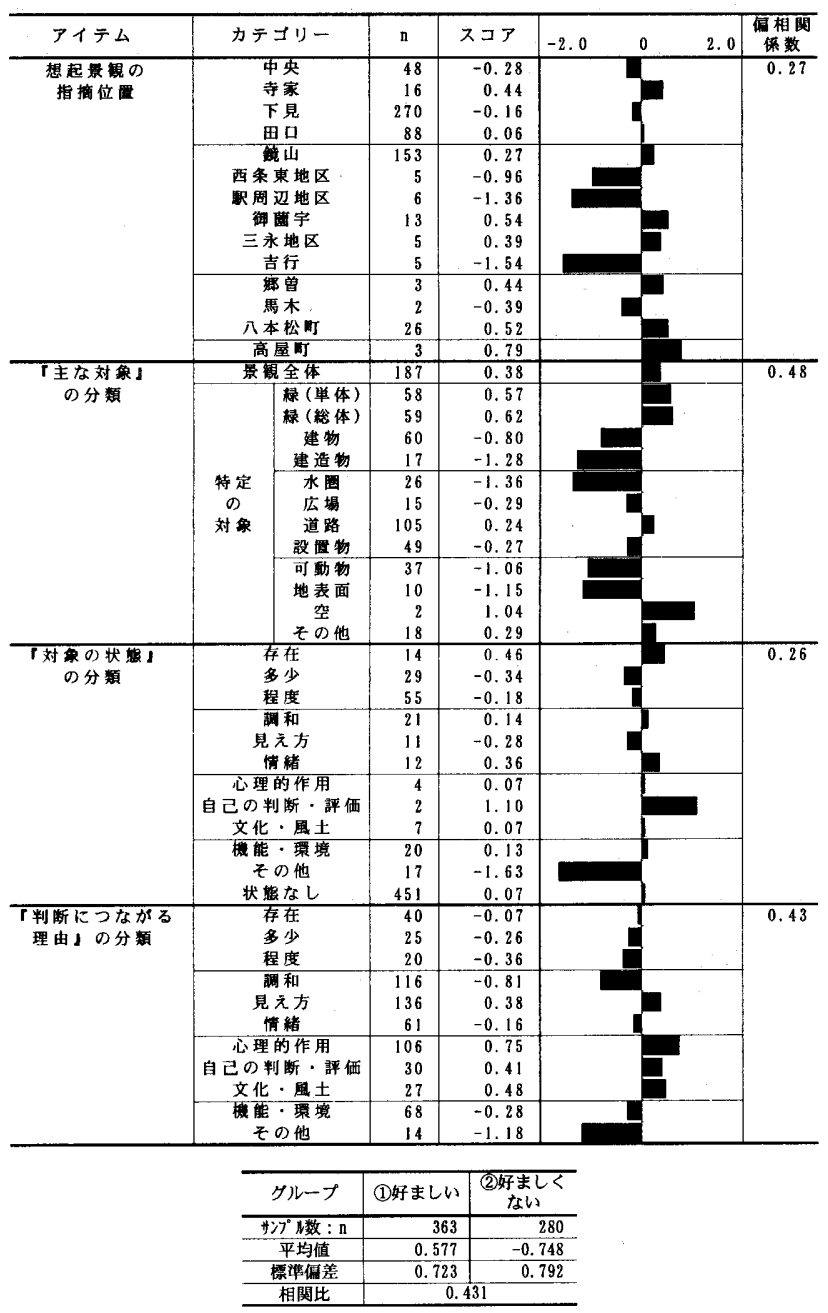

できたと考える。

\section{謝辞}

本調査にご協力いただいた広島大学の学生諸君に感謝の意を表す る。ならびに、研究の遂行にあたって、広島大学 平成 15 年度修了 生の山本一馬氏に多大なご協力をいただいた。ここに記して感謝の 意を表する。

註

1) 写真撮影を行う調查は、被験者が自ら対象地域に赴き、一定時間自由に行動 する必要がある。天候や時間帯などによっては対象が常に撮影可能とは限ら ないうえに、調查時の行動の範囲内では撮影が不可能となる場合もある。想 起による調査は、行動の制約も無く、各々の認識により景観を選好すること が可能なことから、被験者にとって認識の高い地域を調查対象とした場合、 写真撮影を行う手法に比べて、景観選定の自由度は増すものと考えている。

2) 東広島市は 2005 年 2 月 7 日に近隣の黑瀬町、福富町、豊栄町、河内町、安芸 津町と合併した。これにより、広島県の約 7.5\%を占める。なお、本論文に おいては、合併前を対象として東広島市と称しており、西条町、八本松町、 高屋町、志和町における地域景観に関する調查となっている。

3）イメージを想起させる手法としては、自由に地図を描かせるイメージマップ 法や、建物, 道路, ベンチなどの空間要素の認知を地図で確かめるエレメン 卜想起法があるが、本論文において対象とした通学路は、被験者にとって相 当程度の認識のある経路であるため、前述の手法のように地城に対する認識 の程度を把握する目的ではなく、想起される景観の指摘位置を把握するため に実施している。したがって、本論文では、被験者の描いた概略図を分析対 
象としての認知地図としては捉えていない。

4）被験者とした大学生には、他地域からの入学者も多く含まれているが、いず れの学生にとっても、大学への通学はほほ毎日行われている行動であり、そ れぞれの住居から大学までの地域について、相当程度の認識を有しているも のと予想できる。このため、通学経路上に限れば、各被験者は東広島市に対 する一定の認識を有するといえ、様々な居所の被験者による回答結果を集約 することにより、東広島市の景観特性をある程度明らかにすることも可能と 考えている。

5）被験者の記入した概略図上の矢印の位置を、実際の地図と照らし合わせたう えで地図上に落とし込み、地図を実際の縮尺で、250m $\times 250 \mathrm{~m}$ の領域ごとに区 分し、集計している。

6） 3 成分は、記述文の構成により『対象の状態』と『判断につながる理由』に 分解しており、記述内容についてはある意味同様の尺度での抽出となる。そ のため、キャプション評価法と比べるなら、『対象の状態』はキャプション評 価法の「特徴」には必ずしも対応しておらず、文章の述部である『判断につ ながる理由』に「特徴」印象」が分離されずに含まれていることになる。

7）自由記述回答の分類においては、文章の並び方を根拠とした。したがって、 記述文の内容が『対象の状熊、『判断につながる理由』のいずれにも解釈可 能な場合、分類の決定にあたって、回答者の意図と研究者の判断が相違する 可能性が存在する。しかしながら、文章の内容卢前後の文脈に留意し、判断 が難しい場合には研究者らの合議によって決定するなぞ、然意性を極力排除 するよう努めており、ある程度の妥当性を有する結果であると考えている。

\section{参考文献}

1）村川三郎, 西名大作, 安野 淳 : 住民による地域の伝統的みどり景観の評価構造 に関する研究，日本建築学会計画系論文集，第509号，pp.77-84，1998.7

2）金 華，西名大作，村川三郎，飯尾昭彦 : 英国・日本・中国の被験者による 河川景観評価構造の比較分析, 日本建築学会計画系論文集, No. 544, pp. 63 $-70,2001.6$

3）西名大作，村川三郎，金 華，大石洋之：中国・日本の被験者による地域景 観の注視特性と評価構造に関する分析，日本建筑学会計画系論文集，第 557 号, pp. 103-110, 2002.7
4）村川三郎, 西名大作, 村田裕之: コンピュー夕画像処理による河川環境評価 に関する研究 その 1 , 日本建築学会計画系論文報告集, 第 426 号, pp. 45-55, 1991.8

5）西名大作, 村川三郎 : 国内外河川景観の評価特性の比較分析, 日本建築学会 計画系論文集，No. 491，pp. 57-65, 1997.1

6）山本一馬，大石洋之，村川三郎，西名大作 : 東広島市域における地域住民の 景観選好特性に関する研究, 日本建築学会環境系論文集, No. 587, pp. 53-62, 2005.1

7) 古賀誉章, 高明彦, 宗方淳, 小島隆矢, 平手小太郎, 安岡正人 : キャプション 評価法による市民参加型景観調查 その1一都市景観の詒知と評価の構造に関 する研究一, 日本建築学会計画系論文集, No. 517, pp. 79-84, 1999.3

8）小島隆矢, 古賀誉章, 宗方 淳, 平手小太郎 : 多変量解析を用いたキャプシ ヨン評価法データの分析一都市景観の認知と評価の構造に関する研究 その $2-$, 日本建筑学会計画系論文集, No. 560, pp. 51-58，2002.10

9）西村匡達，松本直司，寺西敦敏 : 都市の心象風景の形成・想起要因に関する 研究，日本都市計画学会学術研究論文集，第 27 号, pp. 721-726, 1992

10）澤田幸枝, 土肥博至 : 心象風景が景観の評価構造に及ほす影響, 日本都市計 画学会学術研究論文集，第 30 号，pp. 211-216，1995

11）村川三郎, 西名大作, 大石洋之, 山本一馬 : 東広島市域における被験者の景 観選好特性に関する研究一その 1 調查概要と想起による選好景観の分析一, 日本建築学会中国支部研究報告集，Vol. 25，2002.3

12）讃井純一郎, 乾正雄 : 認知心理学に基づく住環境評価に関する研究(1) レパ ートリーグリッド発展手法による住環境評価構造の抽出, 日本建策学会計画 系論文報告集，№. 367，pp. 15-22，1986.9

13）西名大作, 村川三郎: コンピュー夕画像処理による河川環境評価に関する研 究 その 2, 日本建築学会計画系論文集, 第 494 号, pp. 61-69, 1997.4

14）網藤芳男, 村川三郎, 西名大作, 関根範雄 : 地図指摘法を用いたみどりの認 知と評価，日本建築学会計画系論文集，第 506 号, pp. 31-38，1998.4

15）横田幹朗, 村川三郎, 西名大作, 大場誠一郎 : 水際建築物からの住民撮影眺 望景観に対する非住民被験者による選好特性の検討，日本建築学会計画系論 文集，第558号，pp. 79-86，2002.8 